Let us now consider what these facts disclose concerning the diffusibility of the scarlet fever virus. First let us take the 48 tamilies wherein successful home isolation was conducted. The patients were all children of working men. The houses consisted of a room, kitchen, and scullery on the ground floor, with three bedrooms upstairs. In each house a room was prepared for the patient, generally npstairs ; occasionally, however, the tront room on the ground floor was cleared for his reception. This latter, it may be stated, is separated from the kitchen or living room by a short passage about four feet square and one or two doors. Here, then, is a scarlet fever case inhabiting during the whole course of his illness and convalescence one of the apartments of a house (of dimensions describerl above), while throughout the whole of the same period susceptible children occupy with impunity the other rooms of the same dwelling. Again, let it be noted that in all those households the mother was necessarily obliged to act the double part of nurse and housewife. During those six or seven weeks she had to nurse, to feed, to wash, and to attend to all the wants and requirements of the sick child and meanwhile she was at the same time cook, washer. woman, and general handmaid to the healthy members of the household. Once more, during all those weeks she is passing to and fro between the intected and non-infected apartments as frequently and freely as her multifarious and combined duties demand. In each and all of those 48 houses this went on with perfect safety; there were susceptible children in every one of those houses. Nevertheless, throughout all those weeks, although there were daily and even hourly opportunities presented for the conveyance of infection through the medium of the mother, no transmission occurred.

As already mentioned, in each of the 34 houses of Division III., contact admittedly in each instance first took place a day or two before the occurrence of the second case-an admission strikingly confirmed by the great differences seen in the length of the intervals separating the occurrences in Division III. when compared with those of Division I. It is very far from my desire or wish to appear dogmatic in any way, still I think a reasonable inference from the foregoing observations would favour the view that a healthy nurse or attendant on a scarlet fever case does not in ordinary circumstances carry the infection of scarlet fever, even from one room to another.

For several years now I have been earnestly seeking after a genuine instance of a healthy person playing the part of a medium in the transmission of scarlet fever. I have tacitly encouraged mothers to visit their neighbours' sick children, knowing full well that in this small community where everybody is pretty well known to me I should very quickly discover if any of the visitors conveyed the disease to their own homes. I have seized every opportunity to instigate exposure on these lines in a great many other ways, with so far always the same negative results. For the sake of brevity fomites have not been touched upon; besides the mechanic does not generally carry such encumbrances to his workshop or the factory girl to her mill, and in any case should danger eventually be proved to lurk in fomites some simple regulations could surely be devised to dispose of them and to render them innocuous.

To sum up in this investigation we have had before us, say, Division III. 34 households, and Division IV. 48 households. To put it in other words, we have had under observation 82 different sets of circumstances, each, so far as our present knowledge goes, in every way calculated to promote the transmission of infection in the manner specified, yet no transmission occurs. It may be the weight of the scale containing the virus; it may be the drying or the rapid devitalisation of the virus; or it may be some cause or condition as yet unsuspected which prevents the infection being carried by an attendant or nurse even from one room to another, still the public have a right to demand from the medical profession a positive finding and definite pronouncement of the facts herein related and somewhat cursorily discussed.

In conclusion, let me add a case in point recently seen by me-that of a boy, six years of age, suffering from scarlet fever (there is no hospital provision in this district for scarlet fever). The boy is confined strictly to one room; no one enters it but the mother. Three of his sisters have to-day been notified by the overlooker of the factory where they are employed that they are "stopped" until their brother is well. Now this means a loss of $30 \mathrm{~s}$. a week to these poor people. Strange to say, however, scarlet fever occurred in this family five years ago, and by conscientiously confining the then patient to her room all the others escaped. The mother now resents this enforced loss very much and pertinently asks me why if she did not carry the infection from one room to another five years ago, it can be possible now for her daughters to carry the infection to a factory two miles off?

Netherfielr.

\section{BENCE-JONES ALBUMOSURIA, WITH REPORT OF' THREE CASES.}

By JAMES M. ANDERS, M.D., PH.D., LL.D.,

PROFESSOR OF THE PRACTICE OF MEDICINE AND CLINICAL MEDICINE IN THE MEDICO-CHIRURGICAL COLLEGE, PHILADELPIIA; ATTENDING PHYSICIAN TO THE MEDICO-CHIRURGICAL HOSPITAL, PHILADELPHIA, ETC.;

AND

L. NAPOLEON BOSTON, A.M., M.D.,

BACTERIOLOGIST TO THE PHILADELPHIA HOSPITAL; DEMONSTRATOR IN CHARGE OF THE CLINICAL LABORATORY OF THE MEDICOchirurgical college, PHiladelphia.

ALBUMOSE may appear in the urine as a result of pathological conditions and is dependent upon the decomposition of organised proteids, except in cases of the enterogenic form. It may owe its origin to the action of bacteria upon tissues or it may result from the action of certain chemical poisons (phosphorus). It is also observed in connexion with the various cirrhoses of the liver, acute yellow atrophy, gastric cancer, gangrene, acute or chronic suppuration, acute inflammations of the serous surfaces, leucocythæmia, the acute infectious fevers, after death of the fotus, and normally during involution of the uterus. Rarely has BenceJones albumosuria been observed to be a co-existing feature of primary lesions of the bones (myeloma), and at least one of the cases reported below exemplifies this form of the condition. In 1847 Henry BenceJones presented the first recorded instance before the Royal Society of London ; and three years later MacIntyre published a clinical report of this case. The discovery of Bence-Jones appears to have received but little attention for a period of 26 years when Kühne (Solly reported a questionable case, however, in 1846) detected this substance in the urine; but it was not until 1883 that Kühne published a report of his observation in connexion with the clinical history by Stokvis. In 1889 Kahler and Huppert reported a case from a clinical and chemical standpoint respectively ; Stokvis recorded a second case in 1891, Seegelken a case in 1895, and Bozzolo in 1897 recorded another under the title of "Sulla Malattia di Kahler," thus recognising Kahler as the one first to designate the relation existing between albumosuria and primary bone lesions. Von Rustizky as early as 1873, however, classified these lesions as "multiples myelom." Rosin (Senator), Ewald, Fitz, Naunyn, Bradshaw, Ellinger, J. A. Milroy, and J. H. Wright contributed cases during this year. Vladimer de Holstein, Sternberg, Askanazy, Raschkes, Hamburger, Kalischer, Rostoski, Jochmann and Schumm and A. Gutterink and $C$. de Groff have also made valnable contributions to the literature of the subject.

Since the original publication of Bence-Jones's discovery of albumosuria associated with "osteomalacia fragilis rubra" there have appeared in the literature records of 21 cases in which neoplasm of the bones regarded as probable myelomata was disclosed post mortem. In eight cases the tumours were observed ante mortem. In addition to those cases displaying a co-existence of albumosuria and primary myelomata von Jaksch and Fitz have each found albumosuria in a case of myxcedema and Askanazy noted it to be a prominent feature in one of lymphatic leukemia, while Zuelzer observed this body present in the urine of a dog poisoned by pyrodin. To the above cases, 30 in all, should be added three of albumosuria that occurred in our own experience and are herewith reported.

CASE 1.-A man, aged 32 years, first came under the care of one of us (Boston). The patient was exceptionally well developed and was fond of athletics. He was born in California and had had the diseases of childhood, including scarlet fever at the age of 14 years, after which period he 
enjoyed perfect health except for an attack of malaria at 20 years of age which was followed by several relapses, continuing over a period of more than a year. His father died from Bright's disease at 56 years of age and his mother from apoplexy at 55 years of age ; both were large in stature, weighing over 200 pounds. A brother and a si-ter died during childbood (cause unknown)

The following is the history of the patient's last illnes=. On Sept. 20th, 1900, while working at his trade he fell from the second storey of a building to the cellar, a distance of 20 feet. $\mathrm{He}$ was found ursconscious by his fellow workmen and was taken to the hospital, where he soon recovered consciousness and was allowed to walk to his home. As a result of this fall he complained of sorene is in his back, confined to the lower dorsal and lumbar regions, but he returned to his work a week later. During the latter part of November, 1900, he developed a typical form of herpes zoster affecting the right side. At this time he was voiding, 900 cubic centimetres of a pale urine during the 24 hours. He first noticed intense thirst which was allayed only by drinking large quantities of water. During December he complained of weakness, dimness of vision which caused him to remain from work for a time, and pronounced frontal headaches. Early in January, 1901, he returned to work, when on lifting a piece of timber he was seized with severe pain in the lumbar region accompanied by a feeling of "giving away of the backbone," as he expressed it, and was carried to his home. At this time tenderness could be elicited by deep pressure over the lower dorsal vertebræ, and this was also present, though less marked, over the lumbar vertebræ and crest of the right ilium. There was more or less constant pain in these regions and in the right thigh. Two weeks later he experienced a similar "giving away" in the right hip while ascending the stairs Repeated subsequent attacks of this nature, affecting either the hip or back, were experienced. In February the patient stated that he had lo-t 60 pounds in weight during the previous 12 weeks; he now weighed 135 pounds. There were a decided pallor and a peculiar expression. the eyes having a staring prominence, with certema beneath them, which at times involved the entire face and greatly di-torted the features. Wdema of the hands and feet was present, that of the latter increasing as the disease advancer.

On March 10 hh the patient was seized with intense $p \rightarrow$ in over the reuion of the liver which followed an attrck of vomiting. There was now present a small nodule apparently developing from the eighth rib in the mid-axillary line; this soon grew to the size of a horse-chestnut. Both the patient and the nurse insisted that this lump enlarged during each paroxysm of vomiting, and that firm pressure over the tumour diminished its size and gave the patient almost instant relief from pain. At about this time he complained of pain (cramp-like) in the right thigh and of extreme tenderness on the inner surface of the femur at the junction of its upper and middle thirds. On April 22nd (the date of death) this region displayed a tuwour of the size of a hen's egg, developing from the femur. Neither crepitus (a sym. ptom to which other observers have called attention) nor fluctuation was present. A tumour had also protruded from the posterior border of the right tonsil which interfered with deglutition and prevented the use of solid foods. This mass was also painful, but the mucous surface of the throat presented nothing abnormal.

The area of cardiac dulness was slightly increased downwards and to the left. A soft systolic murmur was audible at the apex and was transmitted for a distance of three inches towards the axilla. There was also a soft systolic murmur heard over the base of the heart (hæmic) and faintly transmitted to the carotids. The pulse ranged from 75 to 120 beats per minute but was slow in proportion to the degree of prostration. Later it became compressible and intermittent. There was no atheroma of the arteries. Epistaxis was copious and frequent. Vomiting both before and after the taking of fond was an early feature and persi-ted throughout. Constipation developed early. Cephalalgia was constantly present in the frontal region but occasionally became parietal and occipital. Upon firm pressure an extremely tender area was detected over the left orbit The hearing was dulled and tinnitus was annoying. Insomnia became marked about Jan. 1st, after which he was unable to sleep soundly without the aid of drugs. Cramps in the lower limbs, at times limited to the thighs, caused great suffering. The voice was husky and the speech was slow and somewhat "drawn." In addition to the decided loss of sight before mentioned and the constant floating of specks before the eyes an ophthalmoscopic examination by L. Webster Fox disclosed choked disc, retinal hæmorrhages, and the white deposits common to chronic nephritis. Marked pain on voiding urine, which continued throughout the act, was a late symptom. The hæmoglobin was found to fluctuate between 52 and 70 per cent.; the red cells varied from $3,500,000$ to $4,100,000$ and the white cells from 8000 to 16,000 per cubic millimetre. The red cells reacted normally to -tains but poikilocytosis was well marked. In the stained specimens the white cells showed nothing abnormal. The urine contained Bence-Jones albumose (vide infra). No necropsy was permitted.

CASE 2. - A man, aged 43 years, married, and temperate as to eating and drinking, came under the care of one of us (Anders) on Nov. 18th, 1901. The family history revealed gout, rheumatism, and intense headaches among his ancestors. The patient had had the diseases of chilohood, including three attacks of measles; he had also been troubled with neuralgia during adolescence. Three years ago he met with a bicycle accident which resulted in a fracture of the right leg, and although recovery ensued he had since then complained of pains in the seat of fracture. One year ago acute articular rheumatism developed and lasted for three weeks. For a considerable period of time he had suffered at intervals from severe celphalalgia affecting the left side of the head. In January, 1901, he first discovered certain urinary phenomena which were interpreted by his former physician as belonging to nephritis; he became dyspnceic and at times suffered from cardiac palpitation. The rheumatoid pains had recurred at brief intervals. There had been no febrile movement observed, but there had been a rapid reduction of the body-weight during the past four months; his usual weight in health was 219 pounds, while when first seen it was 167 pounds. Hand in hand with the rapid loss of weight the strength had also declined and the patient often alluded to a sudden "giving way" of one or other leg wiile attempting to walk. There had been four severe attacks of epistaxis since March 1901. The speech was thick, blurred, and slow; the tone was dry and "leathery," resembling the voice in myxodema. The patient often complained of intensely painful shins, especially when they were warmed by the bed-clothes. Occasional pains affecting the lower extremities and wandering pains about the arms, shoulders, and back were complained of, and insomnia had been a troublesome feature during the past three months, although be slept well for a single night at intervals of several days. Violent headaches in the form of hemicrania affecting the left side had been present for a period of about four month:; this symptom was remittent and occasionally intermittent, but it was exceedingly severe at some portion of each day, particularly during the early morning hours, and demanded anodynes for its relief. Pressure above the left orbit srowed a painful tender spot, corresponding with the point of emergence of the supraorbital nerve. The sexual function had been in abeyance for a considerable period of time. The appetite was poor and the liver function was decidedly sluggish. In order to regulate the bowels the patient had been obliged to use a laxative daily. Vomiting occurred at irregular intervals, at times on rising in the morning, and again, though less commonly, after food. Walking early induced fatigue. The temperature was slightly subnormal as a rule.

The left ventricle was slightly hypertrophied and the aortic second sound was perhaps slightly accentuated, but the pulse was weak, soft, and compressible. No murmurs were audible over the præcordium. The eyes bulged and the gaze was staring; the skin presented a dirty-yellow or sallow colour; the facies expressed suffering as a rule. No tumour masses were detected, although the skull, sternum, and shins were tender to pressure. The urine contained BenceJones albumose, a symptom to which allusion will be made later. Examination of the blood showed that the red cells numbered $3,750,000$ and the white cells 23,000 per cubic millimetre, the hæmoglobin amounting to 60 per cent Poikilocy tosis was marked and the red cells reacted normally to stains. The differential count gave poly morphonuclear $72 \cdot 12$ per cent, large lymphocytes 8.17 per cent., small lymphocytes 11.06 per cent., transitional 29 per cent., and large mononuclear 5.8 per cent. No nucleated red or eosinophilic cells were found. 200 white cells were counted. 
Ophthalmoscopic examination made by L. Webster Fox showed colloid deposits above and below the optic nerve and retinal hæmorrhages in both eyes. There was no evidence of optic neuritis, but there was considerable arterio-sclerosis.

On Jan. 7th, 1902, the patient returned to his home in the country and his physician there reports that on account of racking acute pains in the inferior extremities he was unable to leave his bed. Exertion seemed particularly painful. About one month ago this patient died. No necropsy was permitted.

CASE 3.-A man, aged 33 years, of German descent though an American by birth, first came under the care of one of us (Anders) on Oct. 12th, 1900. The patient's habits as to the use of intoxicants had been rather intemperate up to a few years ago, since which time, however, no stimulants of any description had been used. The following significant family history was obtained: the mother died from cirrhosis of the liver eight months ago ; the father was living at 66 years of age and was alficted with double cataract; he also suffered from gout and rheumatism. One paternal uncle died from Bright's disease. The patient had had the diseases of childhood and from the seventh year of age had annually suffered from an attack of tonsillitis. When 18 years old he had diphtheria, followed by facial paralysis of the left side; this complication was ascribed to the application of caustic to the throat. Complete recovery did not ensue and there is still noted an occasional twitching of the muscles, with a tendency to contracture of the facial muscles of the affected side. An ophthalmoscopic examination made by L. Webster Fox gave this result: "The right eye shows colloid degeneration of the retina as well as sclerosis of the blood-vessels. The white deposits, so characteristic of chronic interstitial nephritis, are defined above and around the macular region. The macula itself has escaped its destructive influences, which accounts for his good vision. There is a suspicion of hæmorrhage here and there throughout these deposits. The optic nerve shows slight infiltration; this may be problematic. The left eye shows a normal fundus. There are no deposits and no destruction of the retina. The arterio-sclerosis of the bloodvessels is not so pronounced as in the right eye. This is rather peculiar, as the blood-vessels of both eyes should present the same characteristics. The pupillary reaction is normal and the muscles are perfectly balanced "

The present illness was discovered six years ago during an application for life insurance, when albumin and tube casts were discovered in the urine. No other subjective or objective signs of kidney disease, however, put in an appearance until three years since, when he first observed some malleolar œdema. This symptom had recurred at long intervals and he had also suffered from occasional headaches during the same period. The physical signs at the time of his first visit showed moderate enlargement of the left ventricle with distinct accentuation of the aortic second sound and slight odema of the legs. The body surface looked pale. These signs have not undergone any noteworthy changes up to the present. The urine contained Bence-Jones albumose and other morohological elements to which detailed reference is made below. Examination of the blood showed that the hæmoglobin amounted to 69 per cent.; the red cells numbered $3,200.000$ and the white cells 40,000 per cubic millimetre. A differential count gave polynuclear cells 65 per cent., large mononuclear 5 per cent., transitional 4 per cent, large lymphocytes 15 per cent, small lymphocytes 10 per cent., and eosinophiles 1 per cent.; there were no nucleated red cells. Poikilocytosis was marked. Apart from some emaciation that has orcurred during the last six months there has been no appreciable change in the general condition of the patient until the present.

THE URINE.

CASE 1. - The urine was of a light straw colour and displayed a persistent froth on shaking; the 24 hours' product equalled 2900 cubic centimetres, having the consistence of syrup, and was faintly acid except for an occasional specimen which was neutral in its reaction; the specific gravity varied from 1002 to 1010 . The quantity of urea was practically normal and the urine was found to be free from sugar The total amount of proteid by the Esbach method equalled 0.27 to 0.35 per cent. It was precipitated by nitric, sulphuric, and hydrochloric acids, but was not soluble in excess except by the aid of heat. 13 other reagents employed for the detection of serum albumin gave decided reaction for that body. ${ }^{\prime}$ Casts were not found at any time. The tests employed have been those suggested by Huppert, Mathes, and Milroy.

1. More striking were the changes observed upon the gentle application of heat to the filtered urine. When heated on a water-bath it showed a slight turbidity at about $50^{\circ} \mathrm{C}$., and at from $56^{\circ}$ to $60^{\circ}$ it became opaque and a white precipitate in the form of coarse flocculi was observed, which for the most part was redissolved at a temperature of from $90^{\circ}$ to $95^{\circ} \mathrm{C}$. A test-tube filled to two-thirds of its depth was placed over the flame of a Bunsen burner so as to heat only the upper third of the column of urine. As the temperature reached from $52^{\circ}$ to $54^{\circ} \mathrm{C}$. an opalescence was observed which developed into a dense cloud at from $56^{\circ}$ to $60^{\circ} \mathrm{C}$. and formed a rather heavy coagulum when heated to a temperature between $60^{\circ}$ and $90^{\circ} \mathrm{C}$. The addition of a few drops of dilute acetic acid to the urine caused the opalescence to appear at a lower temperature $\left(37^{\circ} \mathrm{C}.\right)$. In case the heating was continued at a temperature of from $95^{\circ}$ to $100^{\circ} \mathrm{C}$. this coagulum would disappear (dissolve) in part and often entirely when ebullition was prolonged for one minute, but when allowed to cool the urine became equally as turbid as it was before the boiling temperature had been reached, or even more turbid.

2. Upon the addition of concentrated nitric acid drop by drop to the urine after heating the upper third of the column it caused a precipitate to appear in the track of the acid as it traversed the cold stratum of the urine to the bottom where, after the addition of several drops, a rather dense precipitate of a pink or yellowish hue was seen which on standing developed a golden colour.

3. Nitric acid added drop by drop, shaking after each additional drop, caused a slight pinkish colour, affecting most the heated portion of the column.

4. A specimen of the acidulated urine was gradually heated to the boiling point, cooled and filtered, and the filtrate thus obtained apparently contained but little proteid, displaying a slight opalescence with acetic acid but no pre. cipitate resulted when nitric acid was employed. The latter caused a pink tint to appear which became yellowish on the addition of ammonia.

5. A quantity of the urine was placed in a beaker and heated to from $52^{\circ}$ to $54^{\circ} \mathrm{C}$., cooled and filtered. The precipitate collected was dissolved by washing with a solution of soda of a specific gravity of 116 . When thus prepared it gave well-marked Millon's and biuret reactions. The precipitate, when heated with lead acetate and caustic soda (30 per cent.), became blackened due to the formation of lead sulphide, showing that the precipitate obtained in this manner contains sulphur in considerable amount. Boiling before filtering altered in no way these reactions.

\section{Saturation with Neutral Salts.}

CASE 1.-A quantity of urine was saturated with a neutral solution of ammonium sulphate, which completely precipitated the albumose. Saturation with sodium chloride in neutral solution caused a precipitate of but a portion of the albumose, the filtrate giving a decided clouding upon the addition of a small quantity of dilute acetic acid; but the filtrate from the second precipitate did not contain albumose. The body with which we are dealing differs from proto- and hetero-albumose in that it is not completely precipitated with sodium chloride in neutral solution. It resembles hetero-albumose in that it is precipitated on the addition of acetic acid, after saturation with sodium chloride, or magnesium sulphate, but differs from this body in being precipitated at a temperature of $52^{\circ} \mathrm{C}$. A test.tube containing urine saturated with neutral sodium chloride solution to which a few drops of nitric acid were added gave a precipitate on heating, which disappeared on neari g the boiling point but reappeared upon cooling. Saturation with neutral salt exercised but little effect upon the precipitate caused by-sulphuric and hydrochloric acids. It was also precipitated by tannic and picric acids. After acidu. lating the urine with dilute acetic acid and heating sufficiently to precipitate the albumose the tomperature was raised sufficiently to dissolve it, and upon the addition of a few drops of nitric acid the precipitate did not reappear with the usual rapidity upon cooling. Urine saturated with neutral salt to which a few drops of nitric acid were added and the temperature rapidly brought to the hoiling point showed but little tendency to form a precipitate upon

Boston: New York Medical Journal, 1902 (Albumin in the Urine A New Way for applying Nitric Acid and other Reagents). 
cooling. At times this preciptate did not appear for one or more hours. The method commonly empluyed in these analyses was to saturate the urine with a solution of neutral salt, then a drop or two of dilute acetic acid were added, and the temperature was gradually raised to the boiling point, the urine was filtered bot, and the collected coagulum was then readily dissolved by washing with a solution of soda of a specific gravity of 116, after which it was tested for Millon's, the biuret, and sulphur reactions. The filtrate thus obtaine 1 contained albumose, contrary to what one would ordinarily expect. From 30 to 50 cubic centimetres were placed in a beaker and a drop of hydrochloric acid was added stirring gently, when a few drops of phosphotungstic acid were added and heat was gently applied, which when prolonged for a few minutes caused a copious precipitate to collect at the bottom in the form of a rather tough whitish mass. The clear superna'ant fluid was decanted and this second precipitate was washed and dissolved in a solution of soda of a specific gravity of 116 , adding drop by drop. This usually gave a colourless mixture, but occasionally it was noted to possess a blue tint which disappeared when the specimen was gently heated. A 1 per cent. solution of copper sulphate was now added drop by drop when a purple colour would appear, rapidly changing to a pink or rich claret. On standing a golden yellow precipitate collected at the bottom of the tube. The second precipitate when dissolved was also treated with Millon's reagent and gave a bright red colour.

In Bence-Jones's, Kühne's, and Matthes' cases the proteid contained phosphoru;, while in Milroy's case not a trace of phosphorus was found. No such studies were conducted in connexion with our cases. Neither were Hofmeister's, Noel Paton's, or Hopkin; and Pinkus's methods employed for the crystallisation of this proteid.

Microscopic study showed the urine to contain few leucocytes, an occasional red blood-cell, epithelial cells (bladder), and a few bacteria, cocci and bacilli which were only present in the neutral specimens. No renal casts were found tbough many specimens were centrifugated and carefully examined. Polyuria was present in one of Hamburger's cases in which the patient voided 3500 cubis centimetres daily, while Kahler's patient voided 2230 cubic centimetres. In Case 1 of our series the patient pa-sed 2900 cubic centimetres per diem, while in Cases 2 and 3 the patients passed 2500 and 2300 cubic centimetres respectively.

CASE 2.- The urine was as a rule feebly acid, kut was occasionally nıutral. The 24 hours' product was 2500 cubic centimetres. more recently only 1875 cubic centimetres. There was froth in excess; the urine was of a light straw co our and the specific gravity ranged from 1004 to 1012. The standing specimen showed only a slight amount of sediment. The total proteid estimated by the Esbach method ranged from 0.233 to 0.0012 per cent. Over a period of several months albumose was preient at each analysis, the tests detailed above having been employed. During the last month of life the total amount of proteid was much reduced and a reaction for albumose could not be obtained. In this particular it resembles Stokvis's case in which the albumosuria disappeared three months before death. The albumosuria, however, did not assert itself in his case until late in the course of the disease, and this may have been true of our case since the patient had been ill for a long time and had lost 60 pounds in weight before consultiog one of us (Anders). Microscopically the centrifugated specimens contained bladder epithelium, amorphous urates, few leucocytes, and an occasional red cell. Casts were not found. Certain of the specimens contained many bacteria (motile bacilli) and the question as to how this condition might influence the reactions for the Bence-Jones body naturally suggested itself, and further observation showed that the bacteriuria, when present, exercised no influence upon the reactions for albumose.

CASE 3 - The urine was uiually clear, colourless, and acid; the 24 hours' product equalled 2300 cubic centimetres, the specific gravity ranging from 1008 to 1012. The total amount of proteid estimated by the $\mathbf{E}$-bach method varied from 0.01 to 003 per cent. Serum albumin was always present in large amount. Bence-Jones albumoce which was first found on Oct. 25th, 190 I, was not a constant constituent until recently; it has been of late noted at each examination. When the urine contained albumose it was always noted to be of the consistence of syrup and when a drop was evaporated nearly to dryness it was found to be markedly viscid. This appears to be the sixth recorded instance in which urine containing albumose resembled syrup. In Case 1 of our series it was also observed. Microccopically, small hyaline, granular, and large (so.called amyloid) casts were always present; there were few epithelial cells, and leucocytes were occasionally found. Casts were present in Bence-Jones and MacIntyre's case and mention is made of their having been found in cases cited by Senator, ${ }_{-}$Fitz, Hamburger, and Raschkes.

Albumose resembles, in many respects, histon, which may under certaín conditions be derived from nucleo histon, a proteid of the leucocytes. According to Milroy, histon resembles. more closely globin than albumose and seems to be intermediate in its properties between acid albumin and albumose. Histon is precipitated from acid solutions by ammonia, while in albumose no precipitate occurs. Lilienfeld found that this body (histon) yielded a precipitate when heated, which was soluble in dilute acids. It was precipitated on the addition of nitric acid; this precipitate disappeared on heating, to reappear on cooling It gave a distinct rose-pink colour with copper sulphate and caustic soda. Huppert first ob-erved the resemblance existing between albumose as found in Bence-Jones albumosuria and the proteid constituent of hæmoglobin. Schultz has also studied these bodies and his conclusions are essentially the same as those of Milroy. "Whe two bodies resemble one anorher in their behaviour on the addition of hydrochloric and nitric acids and also in the fact that they both give the biuret reaction. The albumose differs from globin in being less easily precipitated by the addition of neutral salts, in giving a distinct reaction with Millor's reagent and in containing loosely combined sulphur." When precipitated by heat globin is readily soluble in dilute acids, a feature less marked in albumose.

A review of the cases of albumosuria available in the literature, 30 in number, and a more careful study of our own three examples reported above, making a total of 33 cases, appear to warrant the following inferences.

Etiology.-Albumosuria is a condition which manifests itself after the age of 30 years. Of our selies one occurred at 32 , another at 33 , and a third at 36 years of age. Of the cases found in the literature one developed at 24 , another at 37,10 between 40 and 50 , one between 50 and 60 , and seven between 60 and 70 years of age. In the remaining cases the age could not be ascertained. Males are affected in 80 per cent. of the cases. In 15 per cent. of the cases (including two of our own) there is a history of an accident inficting rather severe traumatism. Primary lesions of the bones, which should be regarded as multiple myeloma, figured in 80 per cent. of the cases. Of thes the bones of the chest, vertebræ, and pelvis suffered most destruction, while one-fourth likewise presented involvement of the long bones-femur, radius, and humerus. An extreme grade of anæmia has been regarded by many writers as a predisposing factor, while others consider the anæmia to be secondary to myeloma. According to the blood-findings in our own cases, the latter view is probably the correct one. Experimentally, albumosuria results from the administration of pyrodin.

Symptomatology. - Albumosuria may be persistent, transitory, or less commonly remittent, rccurring in variable degrees at different hours during the day. In certain of the cases the urine presented this phenomenon (albumosuria) after the disease was well advanced. while in uthers it disappeared when the disease was at its height. Where the urine contained both serum albumin and albumose the former has been noted to be absent a few days before death. In but two instances was the percentage of albumose estimated. The specific gravity ranged from 1040 to 1004 , In six cases, inclu ling two of our own (Nos. 1 and 3), the urine resembled syrup Polyuria is mentioned by Kahler, Kalischer, and Hamburger and has been prominent feature in our three cases. Sesum albumin is stated to have been found in conjunction with albumose in 30 per cent. of the cases, nearly all of which showed either hvaline or amyloid casts. A small amount of serum albumin was present in two of our cases, in the third the percentage was large, while only one of them showed tube casts. We are forced to regard albumosuria as a condition not dependent upon an $\mathbf{k}$ known pathological changes in the kidneys themselves, but one that may appear in connexion with renal lesions. Pain is an almost constant feature, a single exception existirg. It is usually referred to as bone pains, rheumatism, lumbago, neuralgia, \&c. The pain occurs without apparent cause, is severe, and is often accompanied by a "giving away" of some portion of 
the buny skeleton. At times it is dull and constant, again cramp-like, lancinating, and momentary. Pressure over painful bones intensifies it, as does also exerci:e. While the pains are commonest over the flat bones the extremities often share this agonising symptom. Cramps involving the lower extremities are common. Toothache, loosening of teeth, maxillary necrosis, and salivation may develop. Painful deglutition developed late in Case 1 of our series. Facial neuralgia is mentioned in connexion with 30 per cent. of the cases. Paralysis of the hypoglossal nerves and of the third division of the trifacial nerve is reported. One of our cases (No. 3) showed paralysis and twitching of the left side of the face. Cephalalgia is mentioned as a prominent symptom in 70 per cent. of the cases. In Cases 1 and 2 of our series it was most troublesome and in Case 3 it developed periodically. Hand in hand with rapid and progressive emaciation are noticed pallor, anæmia, prostration, and gastro-intestinal symptoms, as nausea, vomiting, diarrhœa, and constipation. In one instance jaundice developed early.

Deformities -.In 67 per cent. of all cases deformities involving the bones of either the thorax, pelvis, spine, cranium, maxilla, or extremities were apparent during life. Pathological fractures occurring without apparent cause are a common complication and were observed in one-fourth of all cases. Glandular enlargement is recorded in connexion with 15 per cent. of the cases, but in none of these did microscopic study show the growths of the glands to be identical with those developing from the bones.

Frequent painful micturition was a late symptom in one of our cases. The urine is said to have been passed frequently in four other cases. Epistaxis proved an early and annoying symptom in two of our cases and was occasionally present in the third. Changes in the voice are recorded in $16 \frac{2}{3}$ per cent. of the cases, while in $12 \frac{1}{2}$ per cent. impairment of the auditory function existed. rachycardia, palpitation, and dyspnce are repeatedly referred to in the literature and were prominent in our cases. Insomnia was present in three of the cases furnished by the literature and in two of our series (25 per cent. of the cases). A moderate degree of pallor has been a constant feature. The skin is dry and harsh and at times presents a muddy or dirty yellow colour.

Mention is made of impairment of vision in four cases furnished by the literature. One developed glaucoma and another showed strabismus and double vision. In our cases failing sight was an early and progressive symptom. Ophthalmoscopic examination revealed sclerosis of the vessels, colloid degeneration of the retina, retinal hæmorrhages, and the white deposits common to chronic nephritis Reference is made to a rather severe progressive anæmia in most of the cases ; for example, in those of Ellinger, Askanazy, Vickery, Musser, and Fitz, whilst in our series it was more moderate. Record of a complete bluod examination appears in connexion with but eight cases, including the three herein reported. Our cases showed leucccytosis of $16,000,23,000$ and 40,000 per cubic millimetre respectively, red cells between $3,200,000$ and $3,750,000$, and hæmoglobin between 60 and 70 per cent. Fosinophilic cells were diminished in one and absent in two. Pneumonia as a complication is given as a cause of death in $12 \frac{1}{2}$ per cent. of the cases. The duration of the condition is usually less than two years; one case, however, is recorded in which albumosuria persisted for more than eight years.

Bence Jones albumose is a body more or less closely allied to peptones, globio, histon, and the digestive albumoses, but it displays certain characteristics unknown to these substances. It is a normal constituent of spermatic fluid, and may be found in the bone marrow in cases of myeloma. In conclusion, Bence-Jones albumose when present in the urine is invaluable as a diagnostic feature in cases of obscure multiple myeloma in which no other symptoms of this disease exi-t. It also serves in differentiating maltiple myeloma from other bone lesions, as carcinoma, sarcoma, osteomalacia, \&c. Albumosuria, if continuous, is of grave prognostic significance and but a single exception is recorded wherein the disease has not proved fatal in less than two years. Where the albumose has persisted for some time its disappearance signifies approaching danger and probably an early fatal issue. Since serum albumin is a common co-existent of Bence-Jones albumo-e its dis appearance from such urine may also presage complications of a serious character.

Bibliography.-Askanazy: Dentsches Archiv für Klinische Mericin, 1990, Band lxvili., S. 34. Bence-Jones, Henry : Philosophical Transact ions
of the Royal Society, 1848, Rt. 1, p. 55 . Blair : Brit. Med. Jour., 1901. vol, 1i., p. 713. Bozzolo: VIII. Congresso di Medicina, 1897, Trunsac tions. Brailshaw : Transactions of the lioyal Medical and Chirurgical Society, London, 1899, p. 25l. (For discussion of this report see Proceerlings of the Royal Merlical and Chirurglcal Society. third series, Archiv für Pathologie, Klinische Medicin, und Bacteriologie, 1899 , vol. vii., p. 11 (Russian) Butlin: Transactions of the Pathological Society of London, 1879, vol. xxxi., p. 277 . Coates : Glasgow Medical Journal, 189L, vol. xxxvi., p. 420. Councilman : Journal of Experimental Medicine, 1898, vol. iii., p. 401. Dairymple, M. : Dublin Quarterly Journal of Medical Science, 1846, p. 85. Dreschfield, cited by
Mitroy. Ellinger : Dentsches Archiv fïr Klinische Medicin, 1899, Band Mitroy. Ellinger: Deltsches Archiv fïr Klinische Merlicin, 1899, Band
lxii., S. 255. Ewald : Wiener Klinische Wochensehrift, 1897, S. 169. Fitz, $\mathbf{R} \mathbf{H}$ : American Journal of the Medical Sciences, 1898, vol. exvi, p. 30 . Flatan: Munchener Medicinische Wochencehrift, Feb. 16th, 1897, S. 175. Grawitz: Virchow's Archiv. 1879, Band lxxvi., S. 353.
Gutterink and de Groff : Zeitschrift fïr Physiologische Chemie, 1902, Band xxxiv., S. 392. Hamburger, L. P.: Johns Fopkins Hospital Bulletin, vol xii. Hanmer; Virehow's Archiv, 1894, Band exxrvii., S. 280 . Herrick and Hektoen : Medical News, 1894, vol. lxv., p. 339. Infmeister: Cited hy Milroy. Hopkins and Pinkus: Cited by Milroy. Huppert: Neubaur und Vogel's Analyses des Harns, Wiesbaren, 1898, S. 875; also Centralblatt fir die Medicinische Wissenschaften, 1898, No. 28. Iglehart: Associated with Hamburger's case. Jarkacsohn : Berliner Klinische Wochenschrift, 1893, Band xxx.. S. 222. Von Jaksch : Prager Medicinische Wochenschrift, 1892. Band xvil., S. 602. Jochmann and Schumm : Miinchener Medicinische Wochenschrift, 1901. Band xlviij, Prager Medicinische Wochen-chrift, 1889, No. 4. p. 5. Kahler and Huppert: Prager Metieinische Wochenschrift, 1889, Band xiv., S 35. Kalischer: Dentsche Medicinische Wochenschrift, 1901, Band xxvii., S. 54. Klebs: Allgemeine Pathologie, 1889, Band ii., p. 675 . KromBand xxvii., S. 431. Kuhne: Zeitschrift für Biologie, N F., Band 1., 1883, S 210. Kiibne and Stokvis: Zeitcchrift, fur Biologie, 1883,
Band xix., S. 159,209: 1884, Band xx., S. 11. Lilienfeld: Zeitschrift Band xix., S. 159, 209 : 1884, Band xx., S. 11. Lilienfeld : Zeitschrift
für Physiologische Chemie, Strasburg. 1894, Band xviii., S. 473 . für Physiologische Chemie, Strasburg. 1894, Band xviii, S. 473. MacIntyre: Transactions of the Royal Medical and Chirurgical Macintyre: Transactions of the Royal Medical and Chirurgical
Society, London, 1850, vol. xxxii., p. 211. Magnus Levy : Zeitscbrift fur Physiologische Chemie, 1900, Bani xxx., S. 200.
Markwald: Virchow's Archiv, 1895. Band cxll., S. 128. Marschalko: Markwald : Virchow's Archiv, 1895. Band cxl1., S. 128. Marschalko: Archiv fuir Dermatolngie und Syphilis, 1895 , Band xxx, S. 3. Matthes: Verhandlimgen des Congresses fur Innere Medicin, Band xix, S. 476,
1896. Miescher: De Inflammatione Oscium eorumque Anatomia Generali, 4 to 5. Berolini, 1836. Milrov. J. A. Journal of Pathology and Bacteriology, December, 1900, p. 95 . Muller: Deutsches Archiv fur Klintsche Mredicin, 1891, Band xlviii,, S. 57. Naunyn : Deutsche Mediciniscte Wochenschrift, 1898, Vereins Beilage, S. 2L7. Neumister: Lehrbach der Phvsiologischen Chemie, Auflage 1i.. 1897, S. 804. Nothnagel: Festschrift, Rudolf Virehow, Berlin, 1891, Band ii., S. 155. Paltauf. Ergebnisse der Allgemeinen Pathologie und Pathologischen Anatomie, heransgegeben von Lubarsch und Ostertag, 1896, vol. iii., S 676. Paton, Noel : Bramwell and Paton, Report from the Laboratory

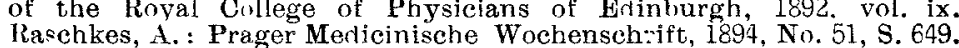
Rnkitansky: Lehrouch der Pathologischen Anatomie. 1856, Band ii., S. 132. Rosin (Senator): Berliner Klinische Wochenschrift, 1897, Band Rostoski: Miinchener Medicinishe Wnchenschrift, 1901. Band xlvii. S. 1115: Deutsche Merlicinische Wochenschrift, 1901, s 224 . Runeherg: Deutsches Archiv fur Klinische Medicin. Leipsic, 1883. Von Rustizky : Deutsche Zeitschrift für Chirurgie, 1873, Band lil., S. 162 Schultz: Zeitschrift für Physiologische Ohemie, Strasburg, 1898, Band xxiv.. S. 449. Seegelken : Deutsohes Archiv fur Klinische
Medicin, 1897 Band lviii., S. 126 and 276 . Senator : Archiv für PatholoMedicin, 1897 Band lviii..s. 126 and 276 . Senator : Archiv für Pathologische Anatomie, \&c., 1874, Band ix., S. 476: also Berliner Klinische
Wochenschrift, 1899, Band xxxvi., p. 161. Simon: American Journal Wochenschrift, 1899, Band xxxvi.,p. 161. Simon: American Journal of the Medical Sciences, June, 1902, p. 939. Solly : Dublin Quarterly
Juurnal of Merical Science, June, 1846. Solon Martin : Solon's Treatise, p. 423 (De l'Albuminurie). Specimens preserved in the Patholngical Museum of University College, Liverponl Spencer Brit. Med. Jour., Jan. 18th. 1896. Sternherg : Nothnagel's Specielle
Pathologie und Therapie, 1899, Band viii., Theil 2, Abthellung 2, S. 57 and S. 83 . Stokvis : Nederlandsche Tijdschrift voor Geneeskunde, 1981, vol. ii., p. 36, cited in Maly's Jahresbericht, 1892, vol. xxi., p. 412 . Thomas : Boston Medical and Surgical Journal. Oct. 3rd, 1901. Vickery: International Clinics, 1902. Virchow : Die Krankhaften Geschwiulste, Band ii., S. 7. Berlin, 1864. Vladimer de Holstein : La Semaine Médicale, 1898, p. 206 ; and 1899, p 82 . Waldstein : Virchow's Archiv, 1883, Band xcl.. S. 12 Wehr, F. P.: Journal of Pathology and Bacteriology, January, 1898. Weber, Hermann : Transactions of the Pathological Society of London, 1866, vol. xviii., p. 206. Wieland : Primare Multiple Sarcoma der Kncch $n$, Inaugural Dissertation, Basle, 1893. Williams : citer by Branshaw. Winkler: Virchow's Archiv, Medical Science, vol. iv., April, 1900; Transactions of the Association of American Physicians. vol. xv.. 1900. Zahn, F. W.: Deutsche Zeitschrift fiir Chirurgie, 1885, Band xxii. Zeinnisen (Stokvis): Jahresxxiii. S. 577. Zuelzer: Berliner Klinische Wochenschrift, Oct. 1st, 1900,37 Jahrgang, No. 40.

Philadelphia.

An American Patent. - An American inventor has patented "a combinen lid or cover and canopy for coffins and caskets." "The specification and drawing are given in the Official Gazotte of the United States Patent Office issued on Dec. 16th. The illustration shows a hinged or jointed framework attached to the upper edge of a coffin, by means of which framework the lid may be supported at a height above the coffin approximately equal to the depth of the coffin itself. The purpose therehy intended to te served is not stated. 